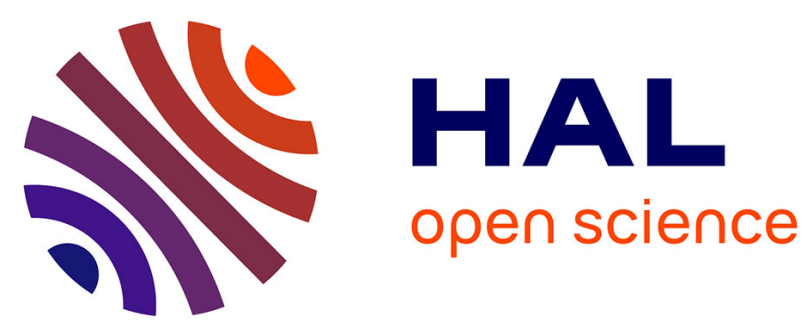

\title{
The Dryline on 22 May 2002 during IHOP_2002: Convective-Scale Measurements at the Profiling Site
} Belay Demoz, Cyrille Flamant, Tammy Weckwerth, David Whiteman, Keith Evans, Frédéric Fabry, Paolo Di Girolamo, David P. Miller, Bart Geerts, William Brown, et al.

\section{To cite this version:}

Belay Demoz, Cyrille Flamant, Tammy Weckwerth, David Whiteman, Keith Evans, et al.. The Dryline on 22 May 2002 during IHOP_2002: Convective-Scale Measurements at the Profiling Site. Monthly Weather Review, 2006, 134, pp.294-310. 10.1175/MWR3054.1 . hal-00068865

\section{HAL Id: hal-00068865 https://hal.science/hal-00068865}

Submitted on 11 Feb 2021

HAL is a multi-disciplinary open access archive for the deposit and dissemination of scientific research documents, whether they are published or not. The documents may come from teaching and research institutions in France or abroad, or from public or private research centers.
L'archive ouverte pluridisciplinaire HAL, est destinée au dépôt et à la diffusion de documents scientifiques de niveau recherche, publiés ou non, émanant des établissements d'enseignement et de recherche français ou étrangers, des laboratoires publics ou privés. 


\title{
The Dryline on 22 May 2002 during IHOP_2002: Convective-Scale Measurements at the Profiling Site
}

\author{
Belay Demoz, ${ }^{*}$ Cyrille Flamant, ${ }^{+}$Tammy Weckwerth, ${ }^{\#}$ David Whiteman, ${ }^{*}$ Keith Evans, ${ }^{@}$ \\ Frédéric Fabry, ${ }^{\&}$ PaOlo Di Girolamo, ${ }^{* *}$ David Miller, ${ }^{+}+$Bart Geerts, \#\# William Brown, \#\# \\ Geary Schwemmer,*3Ruce Gentry,* Wayne Feltz, ${ }^{@}$ And Zhien Wang ${ }^{@}$ \\ *NASA Goddard Space Flight Center, Greenbelt, Maryland \\ + Institut Pierre-Simon Laplace/Service Aéronomie, Paris, France \\ \# National Center for Atmospheric Research, Boulder, Colorado \\ @ University of Maryland, Baltimore County, Baltimore, Maryland \\ \& McGill University, Montreal, Quebec, Canada \\ ** Università degli Studi della Basilicata, Potenza, Italy \\ ++ Science Systems and Applications, Inc., Lanham, Maryland \\ \#\# University of Wyoming, Laramie, Wyoming \\ @@CIMSS/SSEC, University of Wisconsin-Madison, Madison, Wisconsin
}

(Manuscript received 18 August 2004, in final form 5 July 2005)

\begin{abstract}
A detailed analysis of the structure of a double dryline observed over the Oklahoma panhandle during the first International $\mathrm{H}_{2} \mathrm{O}$ Project (IHOP_2002) convective initiation (CI) mission on 22 May 2002 is presented. A unique and unprecedented set of high temporal and spatial resolution measurements of water vapor mixing ratio, wind, and boundary layer structure parameters were acquired using the National Aeronautics and Space Administration (NASA) scanning Raman lidar (SRL), the Goddard Lidar Observatory for Winds (GLOW), and the Holographic Airborne Rotating Lidar Instrument Experiment (HARLIE), respectively. These measurements are combined with the vertical velocity measurements derived from the National Center for Atmospheric Research (NCAR) Multiple Antenna Profiler Radar (MAPR) and radar structure function from the high-resolution University of Massachusetts frequencymodulated continuous-wave (FMCW) radar to reveal the evolution and structure of the late afternoon double-dryline boundary layer. The eastern dryline advanced and then retreated over the Homestead profiling site in the Oklahoma panhandle, providing conditions ripe for a detailed observation of the small-scale variability within the boundary layer and the dryline. In situ aircraft data, dropsonde and radiosonde data, along with NCAR S-band dual-polarization Doppler radar (S-Pol) measurements, are also used to provide the larger-scale picture of the double-dryline environment.

Moisture and temperature jumps of about $3 \mathrm{~g} \mathrm{~kg}^{-1}$ and $1-2 \mathrm{~K}$, respectively, were observed across the eastern radar fine line (dryline), more than the moisture jumps $\left(1-2 \mathrm{~g} \mathrm{~kg}^{-1}\right)$ observed across the western radar fine line (secondary dryline). Most updraft plumes observed were located on the moist side of the eastern dryline with vertical velocities exceeding $3 \mathrm{~m} \mathrm{~s}^{-1}$ and variable horizontal widths of $2-5 \mathrm{~km}$, although some were as wide as $7-8 \mathrm{~km}$. These updrafts were up to $1.5 \mathrm{~g} \mathrm{~kg}^{-1}$ moister than the surrounding environment.

Although models suggested deep convection over the Oklahoma panhandle and several cloud lines were observed near the dryline, the dryline itself did not initiate any storms over the intensive observation region (IOR). Possible reasons for this lack of convection are discussed. Strong capping inversion and moisture detrainment between the lifting condensation level and the level of free convection related to an overriding drier air, together with the relatively small near-surface moisture values (less than $10 \mathrm{~g} \mathrm{~kg}^{-1}$ ), were detrimental to $\mathrm{CI}$ in this case.
\end{abstract}

Corresponding author address: Belay B. Demoz, NASA GSFC, Code 613.1, Greenbelt, MD 20771.

E-mail: Belay.B.Demoz@nasa.gov

(C) 2006 American Meteorological Society 


\section{Introduction}

The dryline develops in the Great Plains of the United States and is sometimes called a "dewpoint front" or "dry front." It is a boundary between warm, moist air that originated from the Gulf of Mexico and hot, dry air from the Mexican Plateau and southwest desert. It is a favored zone for initiation of severe weather (Rhea 1966; Ziegler and Rasmussen 1998). Across dryline moisture differences, dryline characteristics and motion, potential for convection, and vertical mixing have been reported [see Parsons et al. (2000) and Ziegler and Rasmussen (1998) for references and extended discussions]. These studies have shown that the mere presence of a dryline does not guarantee the occurrence of deep convection, although cumulus and cumulus congestus clouds are frequently observed near the dryline. Even though there are still outstanding questions on how and when storms are initiated along the dryline (Parsons et al. 2000; Ziegler and Hane 1993; Schaefer 1986; Ziegler et al. 1997), preferred locations for convective initiation (CI) have been shown to be related to regions of enhanced updrafts associated with intersecting boundaries and horizontal rolls (Atkins et al. 1998), misocyclones (Kingsmill 1995), mesoscale low pressure areas (Bluestein and Parker 1993), gravity waves (Koch and McCarthy 1982), and "bulges" in the convergence boundary (Hane et al. 1993, 1997). In addition, the quantification of the small-scale variability of boundary layer variables such as moisture, wind, and temperature are important to understanding CI (Weckwerth et al. 1996; Crook 1996; Weckwerth 2000).

This paper focuses on the evolution and variability of the convective-scale moisture and wind in the boundary layer during a dryline event that occurred on 22 May 2002 in the framework of the International $\mathrm{H}_{2} \mathrm{O}$ Project (IHOP_2002). Weckwerth et al. (2004) provide a full discussion of the observational network, measurement strategy, and instruments deployed during IHOP_2002. No significant convection occurred in the area of the intensive observation (the Oklahoma panhandle), but deep convection occurred farther north. A detailed analysis of the evolution of the structure of a double dryline observed over the Oklahoma panhandle and thermodynamic variability of the convective boundary layer $(\mathrm{CBL})$ is presented using observations made at the so-called Homestead profiling site located in the Oklahoma Panhandle. Of primary importance for the discussion in this paper are data from (i) the National Center for Atmospheric Research's (NCAR) Integrated Sounding System (ISS), which consisted of a standard surface meteorology station, a sodar, a radiosonde station, and a UHF wind profiler [the Multiple
Antenna Profiler Radar (MAPR; Parsons et al. 1994)]; (ii) three National Aeronautics and Space Administration (NASA) Goddard Space Flight Center (GSFC) ground-based lidars for remote sensing of water vapor, aerosol backscatter, and wind profiles; (iii) the University of Massachusetts frequency-modulated continuouswave (FMCW) radar (Ince et al. 2003); (iv) the University of Wisconsin Atmospheric Emitted Radiance Interferometer (AERI; Feltz et al. 2003); and other standard meteorological instruments at the Homestead profiling site. In particular, the focus here is on the three GSFC lidars: the scanning Raman lidar (SRL; Whiteman 2003a,b), the Goddard Lidar Observatory for Winds (GLOW; Gentry et al. 2000), and the Holographic Airborne Rotating Lidar Instrument Experiment (HARLIE; Schwemmer 1998). Aircraft in situ, dropsonde, and radiosonde data, along with NCAR Sband dual-polarization Doppler radar (S-Pol) measurements, are also used to provide the larger-scale picture of the double-dryline environment.

The analysis in this work is unique in that it combines simultaneous lidar-based measurements of wind, moisture, and CBL structure with measurements from aircraft, radar, and profiles of infrared moisture and temperature and other standard data to study thermodynamic variability in and around clear-air updrafts during a dryline passage event. To our knowledge, this case represents one of a very few (if not the only) advancing and retrograding dryline cases observed using multilidar, multiradar, and multiaircraft instrumentation in addition to the many other standard instrumentation such as the Oklahoma Mesonet stations.

In section 2, a brief description of the large-scale environmental conditions is presented using satellite, radiosonde, radar, and aircraft data. In section 3, data collected by the Homestead-based instruments on 22 May 2002 are presented. Analysis and synthesis of the data are presented in section 4. A summary as well as conclusions is presented in section 5 .

\section{Data and analysis: The large-scale environment}

\section{a. Satellite data}

Satellite, upper-air soundings, and surface analyses for this day (not shown) indicated that a major upperlevel trough was approaching the northern high plains with strong south-southwesterly flow ahead of the system. At the same time, the southern plains were under a moist southerly flow and a stratocumulus layer was visible over most of eastern Oklahoma and east of a dryline, oriented roughly north-south and extending from the Texas panhandle into western Kansas. This dryline can be identified as a fine line on the radar 


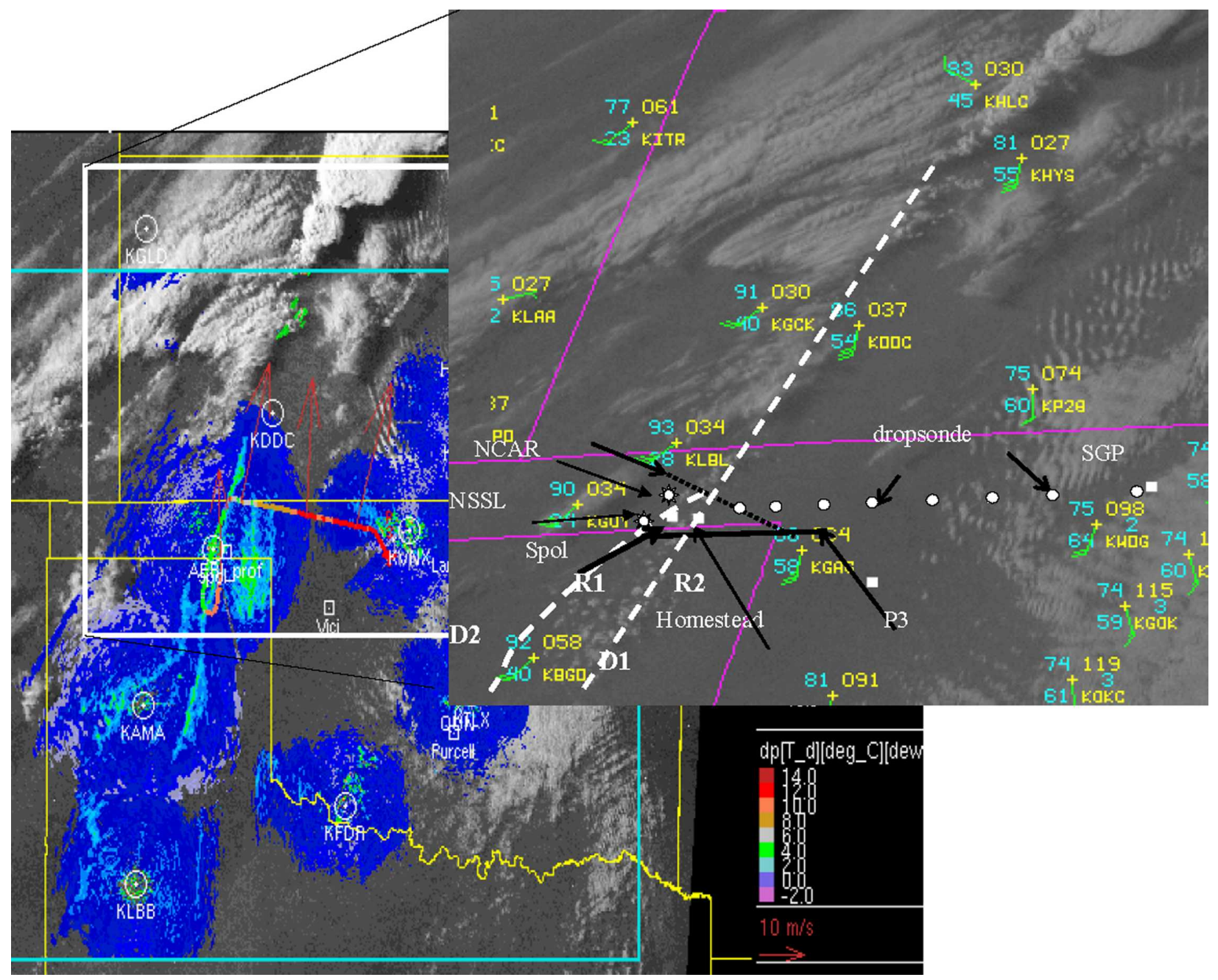

FIG. 1. GOES satellite image of most of the IHOP_2002 domain on 2332 UTC 22 May 2002 overlaid with radar reflectivity and aircraft (P-3) in situ measurements of dewpoint temperature and in situ aircraft wind observations. An expanded view of the GOES image showing surface observations and locations of the profiling site (Homestead), S-Pol radar (square), NSSL and NCAR sonde release points, aircraft flight paths (solid line for NRL P-3 and dotted for UWKA flight legs), Learjet dropsonde locations (circles), and the ARM Cloud and Radiation Testbed (CART) site [southern Great Plains (SGP)] is also shown. Note the "wedge"-shaped region of cumulus clouds (R1) was bounded by radar fine lines (D2 to the west and D1 to the east) that start south of Amarillo, TX, and extend north across the profiling site into Kansas to the base of the convection. These fine lines were also the approximate locations of the drylines (white dashed curves). Region 2 (R2) is the air mass east of the main dryline.

composite (Fig. 1). The presence of a second radar fine line intersecting the main fine line just north of Homestead is also seen on the radar composite. Much of the area southwest of the Oklahoma and Texas panhandles was under the influence of a dry and hot air mass that traveled over Arizona and New Mexico. By about 2100 UTC [hereafter all times UTC; UTC $=$ central daylight time $(\mathrm{CDT})+5 \mathrm{~h}$ ], Geostationary Operational Environmental Satellite (GOES) visible imagery revealed a wedge-shaped area of cumulus $(\mathrm{Cu})$ clouds oriented roughly NNE-SSW that extended from the Texas panhandle to the Oklahoma-Kansas border (Fig. 1) and delimited by the location of the two radar fine lines, further referred to as D1 and D2, D1 being the eastern dryline. The wedge-shaped region appeared almost stationary and was visible in GOES images until about 0030, although S-Pol and Homestead-based instruments revealed that it did advance and then retreat over Homestead as will be shown later. GOES images also showed that convection was triggered in northern Kansas. Much of the IHOP_2002 aircraft and mobile ground instrumentation discussed in this paper was made well south of the area of convection-in the vicinity of the S-Pol and Homestead. 


\section{b. NCAR S-Pol radar data}

In this study, the NCAR S-Pol radar data are presented to show the advancing and then retreating dryline over the Oklahoma panhandle and to assess the relative location of Homestead vis-a-vis the larger-scale picture of the double-dryline environment. S-Polderived reflectivity, refractivity, and 5-min refractivity changes are used. A description of the S-Pol data products available during IHOP_2002 and on this day is given in Weckwerth et al. (2005). Refractivity data (see Fabry 2004) were retrieved whenever $0^{\circ}$ elevation surveillance scans were made by S-Pol, typically every $5 \mathrm{~min}$.

Figure 2 shows a sequence of near-surface reflectivity, refractivity, and 5-min refractivity changes between 2100 and 0000 as well as a time series of S-Pol-derived refractivity at Homestead. For comparison purposes, and to show that the refractivity changes were not only limited to near-surface changes, the refractivity calculated from surface measurements as well as SRL and AERI (discussed later) data at an altitude $500 \mathrm{~m}$ above Homestead is given. A more thorough IHOP_2002 refractivity intercomparison can be found in Weckwerth et al. (2005).

The reflectivity field (Fig. 2) revealed that the two radar fine lines became more distinct with time and that the stronger echo was associated with the eastern boundary (D1). A movie of the complete 5-min data for this day revealed that the fine lines moved east far enough for the eastern boundary (D1) to advance past Homestead and retreat back over Homestead again. The western convergence line (D2) did not cross over Homestead but most of the well-mixed region (R1) was sampled by the Homestead instrumentation.

The time sequence plots of S-Pol refractivity show the cool moist air mass of higher refractivity (blue area, labeled R2 in the 0000 reflectivity image in Fig. 2) being pushed east and replaced by a SSW-NNE wedgeshaped area of warm/dry air from the southwest (green area, labeled R1) before moving back west again over Homestead, consistent with the surface wind direction (indicated by arrows). Figure 2 (bottom) shows that Homestead was under hot/dry air within R1 between about 2140 and 2230. Note that, using an average surface wind speed of $14-15 \mathrm{~m} \mathrm{~s}^{-1}$ (and assuming that the dryline did not stall long east of Homestead before retrograding), the time spanning the two overpasses of the eastern dryline during its advance and retreat (50 min) corresponds to a 42-45-km-wide dry/warm-air incursion-about twice the $20-\mathrm{km}$ distance between the edges of the cumulus field (Fig. 1) at the latitude of Homestead. This confirms that the Homestead profilers have sampled most (if not all) of the region under the wedge-shaped cumulus clouds (R1). The associated 5-min refractivity changes, while revealing the existence of dry and moist areas (blue and red regions, respectively) of width ranging between 2 and $10 \mathrm{~km}$ along the boundaries, show a more homogenous region of low-level refractivity change (indicated by two lines shown at 0000) corresponding to the well-mixed air mass in the wedge-shaped area.

Another interesting feature in the S-Pol reflectivity image at 0000 (Fig. 2, top, and also seen in Fig. 1 east of Homestead) is the enhanced echo return about 20-25 $\mathrm{km}$ east of the eastern dryline (D1) and labeled R3. This region of increased refractivity was associated with a wind convergence zone (discussed in section 4).

\section{c. Time series data at Homestead}

Surface observations of temperature, wind, water vapor mixing ratio, and precipitable water vapor at Homestead between 1500 on 22 May and 0600 on 23 May 2002 are plotted in Fig. 3. Approximate locations of D1, R1, and R2 (from Fig. 2) are also indicated. Surface wind direction varied between southwesterly and south-southeasterly during the entire day, typical of dryline passages (Schaefer 1974). Wind speeds were between 13 and $15 \mathrm{~m} \mathrm{~s}^{-1}$ on average with values as low as $10 \mathrm{~m} \mathrm{~s}^{-1}$ at 1200 (not shown), just prior to the start of a steady increase in precipitable water vapor (PWV) amounts. Dewpoint temperatures around 1900 were approximately $10^{\circ} \mathrm{C}$ at Homestead, dropping to $-5^{\circ} \mathrm{C}$ in Guymon, Oklahoma, about 30 miles to the west. Superimposed in the diurnal temperature and humidity trends for the day are two dry regions centered about 1700 and 2200 UTC. Mixing ratio values were 9-10 g $\mathrm{kg}^{-1}$ between 1200 and 2400, except around 1700 and 2200 when mixing ratio values decreased to about 8 and $7 \mathrm{~g} \mathrm{~kg}^{-1}$, respectively. Since most of the lidar profilers at Homestead became operational after 1700, we limit our discussion to measurements acquired during the later period.

The surface measurements between 2130 and 2230 exhibited several oscillations of moisture, temperature, and wind direction ( 5-9 min wide). At an average wind speed of $15 \mathrm{~m} \mathrm{~s}^{-1}$, the time-space conversion suggests the existence of features of width between 4 and 8 $\mathrm{km}$, populating this region. Note that comparable scales were also noted in the refractivity change plots, contributed mainly through the moisture (wet) term, in $\mathrm{S}-\mathrm{Pol}$ refractivity measurements discussed above.

\section{d. Sounding data}

Several sounding units operated on this day. A Learjet dropped eight dropsonde packages along a line 

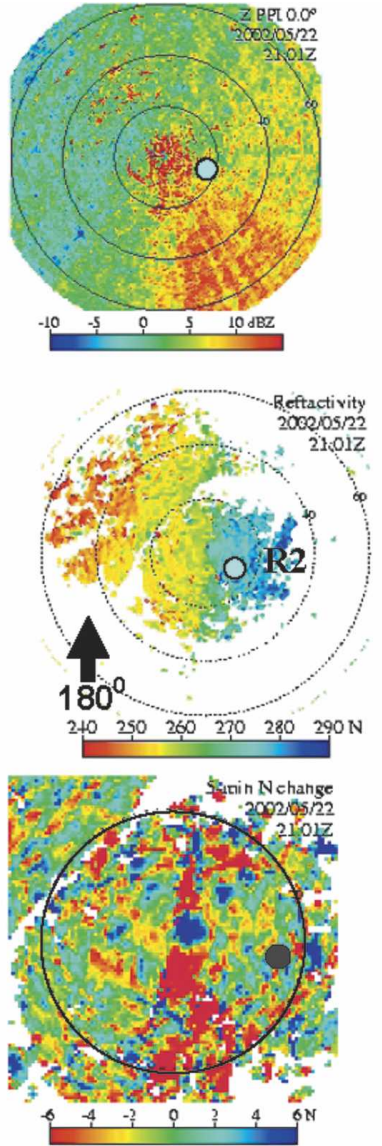
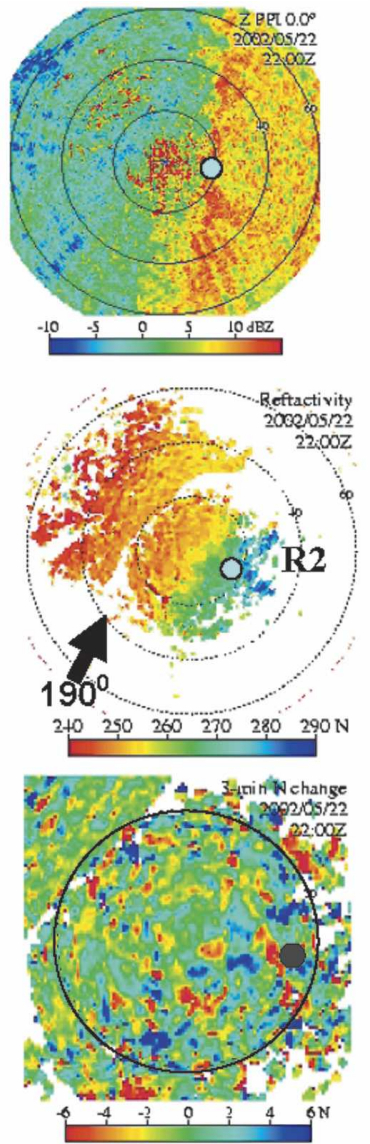
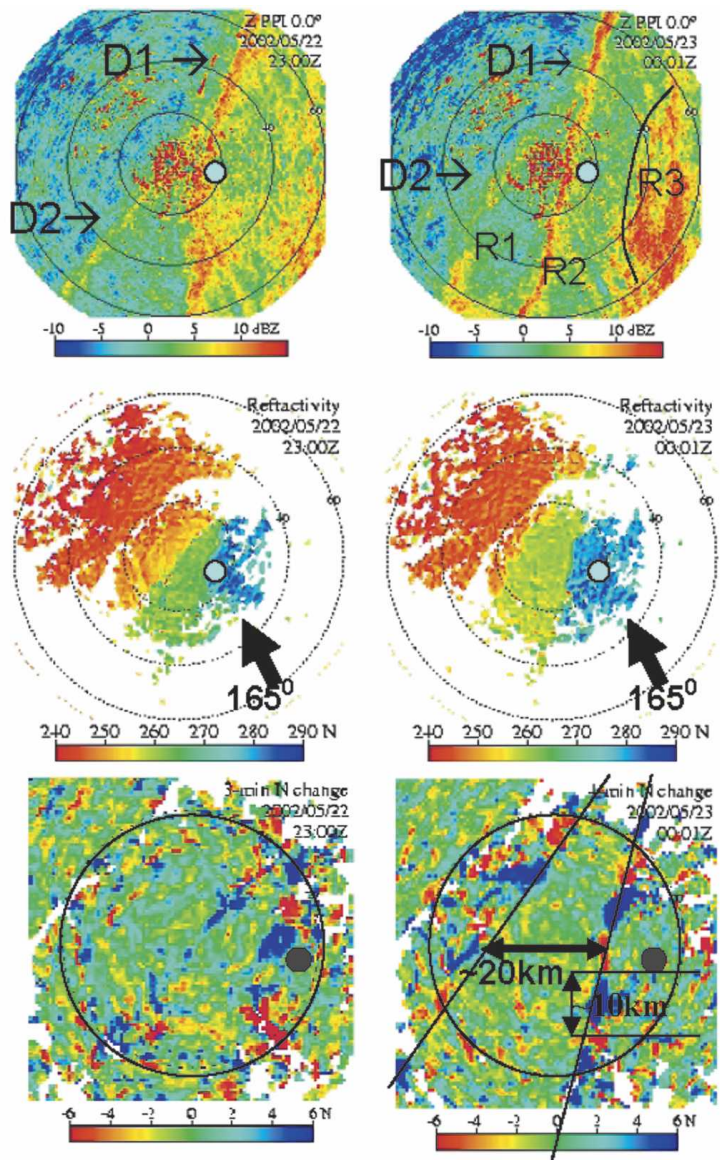

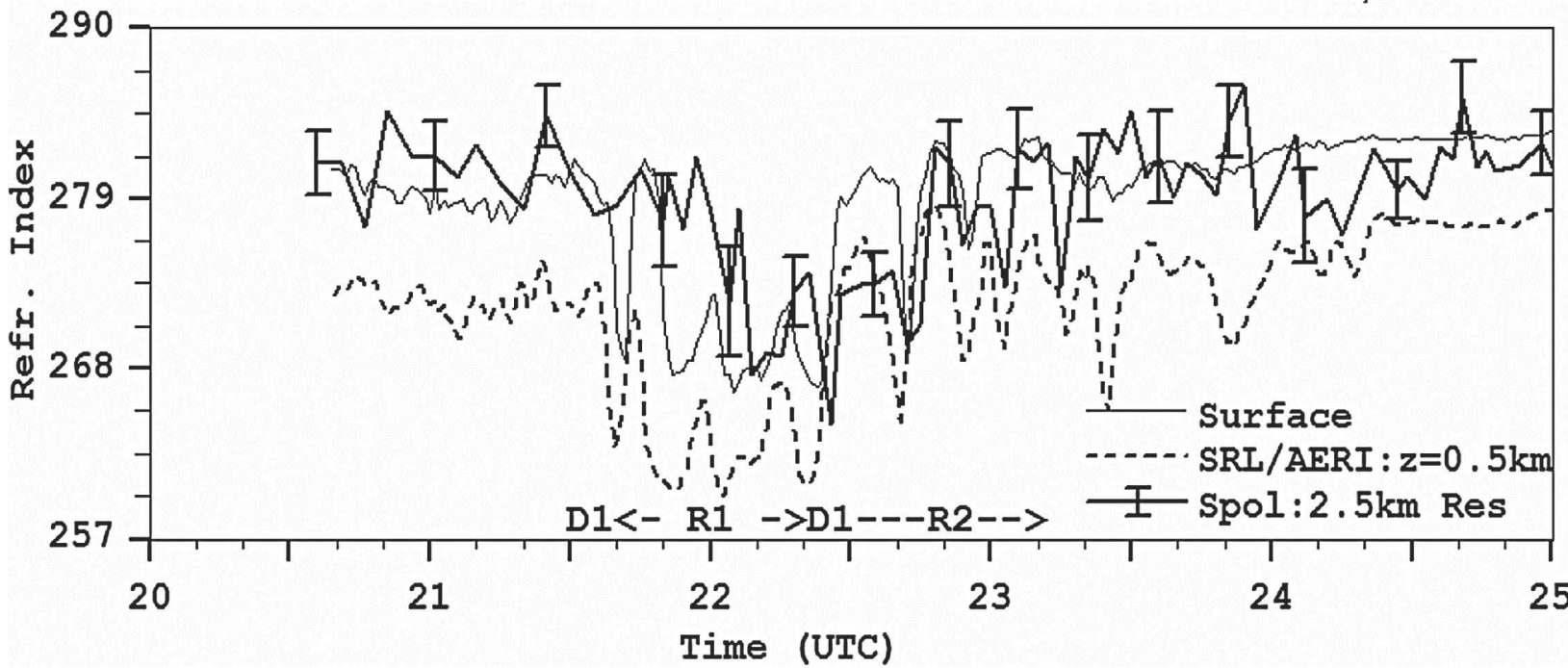

FIG. 2. (top) Time sequence (2101, 2200, 2300, 0000 UTC) of reflectivity, near-surface refractivity, 5-min surface refractivity change obtained by the NCAR S-Pol radar, and surface wind collected over the IHOP_2002 profiling site. The range rings for the reflectivity and refractivity are shown at 20,40, and $60 \mathrm{~km}$, and only the $20-\mathrm{km}$ ring is shown in the 5-min refractivity change panel. (bottom) Time series of refractivity at Homestead derived from surface observation (thin), from SRL and AERI measurements at $0.5 \mathrm{~km}$ (dash), and from S-Pol (with errors, at 2.5-km resolution) are plotted. Location of the IHOP_2002 profiling site (black dot near the 20-km ring) and the dryline convergence zones (D1, D2), as well as regions of different air mass that were sampled at Homestead (R1, R2, R3), are indicated. 


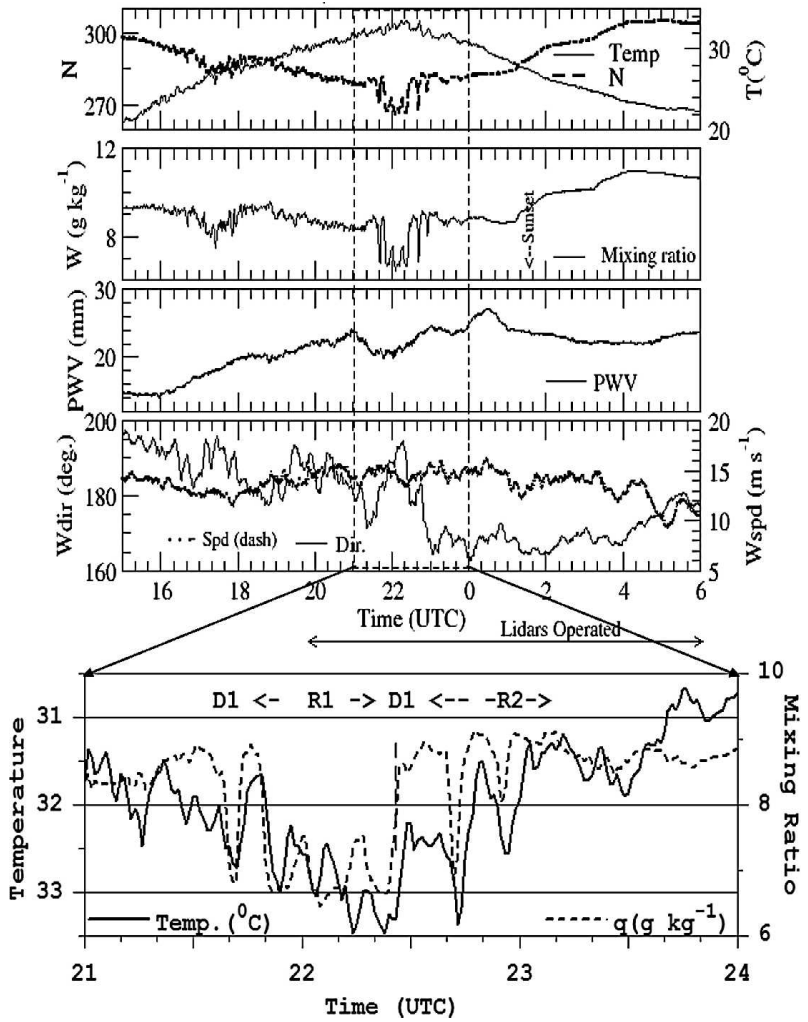

FIG. 3. Surface-based measurements of temperature, refractive index $(\mathrm{N})$, water vapor mixing ratio, precipitable water vapor, wind speed, and direction on 22 May 2002 at the IHOP_2002 profiling site. An expanded view of the temperature and mixing ratio data between 2100 and 0000 on 22 May is also shown. The dry/warm airmass intrusion (R1) associated with southwesterly winds and its subsequent replacement by moist, cool, and a more easterly wind regime (R2) are indicated. Note that the temperature scale is reversed for the expanded view.

starting from just east of Homestead and ending in the vicinity of the Atmospheric Radiation Measurement (ARM) Program central facility in Lamont, Oklahoma (see Fig. 1). Mobile sounding units from NCAR and the National Severe Storms Laboratory (NSSL) also released sondes from and around Homestead. Figure 4 shows an east-west cross-section plot made from ground-based radiosondes (first three sondes in the figure made at 2230, 2132, and 2150) and dropsondes released from the Learjet (marked as 1Le-8Le) between 2130 and 2239. Note that since the contours are constructed from data that span about $1 \mathrm{~h}$, "shorter term" waves and changes introduced by boundary layer (BL) evolution occurring within the time duration are excluded.

The figure shows vigorous vertical mixing of moisture to about $3.5 \mathrm{~km}$ above mean sea level (MSL) over Homestead, coincident with the observation of cumulus clouds. Dropsondes released farther east (4Le-8Le) showed increased water vapor mixing ratio at lower levels (below about $2 \mathrm{~km} \mathrm{MSL}$ ) leading to a sharper contrast with the overlying dry air mass. Compared to the air west of Homestead, the low-level moisture was substantial. For example, at $890 \mathrm{~m}$ MSL (surface elevation) around 2235 UTC, the mixing ratio increased from less than $4 \mathrm{~g} \mathrm{~kg}^{-1}$ at locations $\sim 20 \mathrm{~km}$ west of Homestead to more than $9 \mathrm{~g} \mathrm{~kg}^{-1} \sim 28 \mathrm{~km}$ east of Homestead. The region west of Homestead was characterized by a very dry BL, with zero convective available potential energy [CAPE; calculated from a mobile NSSL sounding launched west of S-Pol at 2235; see Doswell and Rasmussen (1994) for extended discussions of CAPE], as well as low surface dewpoint temperatures that decreased rapidly with altitude. In the region just east of Homestead, the air mass was characterized by relatively larger CAPE (1281 and $1668 \mathrm{~J}$ $\mathrm{kg}^{-1}$ for soundings made from Homestead at 2150 and 0140, respectively), low convective inhibition (CIN; -214 and $-2 \mathrm{~J} \mathrm{~kg}^{-1}$, respectively, for the previously mentioned soundings), as well as higher surface dewpoint temperatures and an abrupt drying of the air above. Analysis of regional surface observations for the day, not shown here, revealed that the higher CAPE values were located approximately along the location of the wedge-shaped cloud region adjacent to the main dryline, D1, in Fig. 1.

\section{e. Supporting aircraft observations}

\section{1) In Situ MOISTURE AND VERTICAL VELOCITY DATA}

The University of Wyoming King Air (UWKA) research aircraft and the Naval Research Laboratory P-3 aircraft (NRL P-3) were operational around Homestead for the 22 May 2002 CI mission. Presenting a full-scale analysis of the data from the aircraft is beyond the scope of this study. However, selected legs and data in support of the Homestead profiler data are presented here.

Figure 5 shows the time series of in situ water vapor mixing ratio and vertical velocity acquired by the UWKA at $1.6 \mathrm{~km}$ MSL between 2333 and 2339. The flight leg was oriented NNW to SSE, and located slightly north of Homestead (see Fig. 1). Three distinct regions with different water vapor mixing ratio characteristics are evident: $8-9 \mathrm{~g} \mathrm{~kg}^{-1}$ in the southeast section of the leg (corresponding to $\mathrm{R} 2), 6 \mathrm{~g} \mathrm{~kg}^{-1}$ in the region corresponding to R1, and $4 \mathrm{~g} \mathrm{~kg}^{-1}$ in the northwest section of the leg, corresponding to a region west of D2. The two "jumps" in the mixing ratio structure (about 16-18 km apart) are associated with the two drylines 


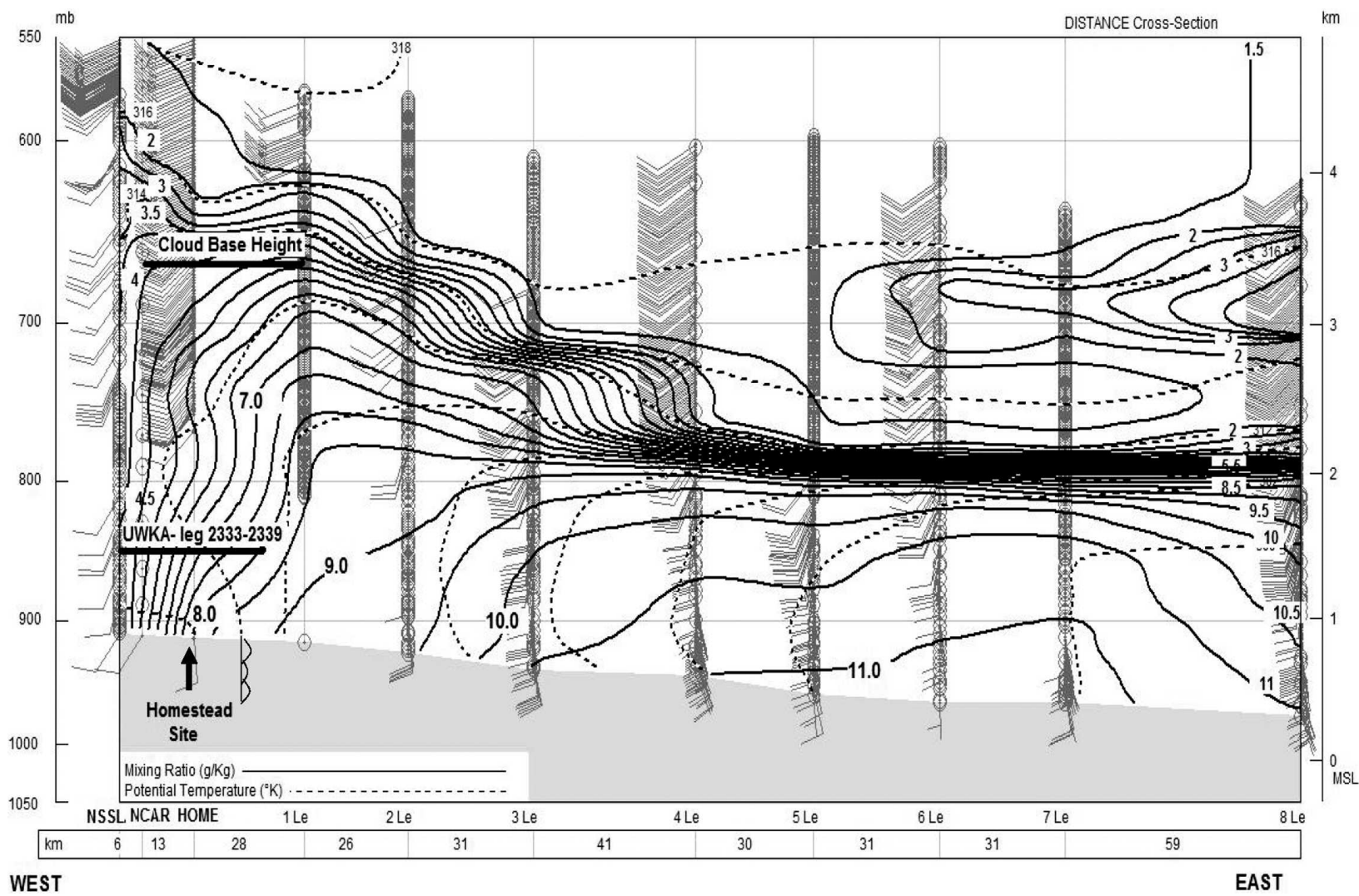

FIG. 4. A cross section of water vapor mixing ratio (solid lines) and potential temperature (dashed lines) from ground- (Homestead, and mobile groups by NCAR and NSSL; first three sonde locations) and aircraft- (Learjet) released dropsondes (release points are denoted by "Le") across (W-E) the dryline. See Fig. 1 for the locations of the sondes. Location of the UWKA leg at $1.6 \mathrm{~km}$ (discussed below), approximate dryline location (between Homestead and 1 Le indicated at bottom), regions R1 and R2, and lidar-derived cloud base are also shown. The distance between the sonde release points is given at the bottom axis, and the topography is indicated by the shading at the bottom of each wind barb plot. The NCAR S-Pol radar was located $18 \mathrm{~km}$ west of Homestead.

discussed earlier. The water vapor mixing ratio change in the western transition, associated with the faint radar reflectivity fine line in Fig. 2, was about $2 \mathrm{~g} \mathrm{~kg}^{-1}$ while the change associated with the stronger reflectivity fine line was $3 \mathrm{~g} \mathrm{~kg}^{-1}$. The area west $(\sim 6 \mathrm{~km}$ or flight of 1 $\min )$ of the eastern dryline was warmer by about $1^{\circ} \mathrm{C}$ (not shown), with respect to region R2, and was characterized by an average vertical velocity of $1.6 \mathrm{~m} \mathrm{~s}^{-1}$. The average vertical velocity associated with the western dryline was near zero on average with a magnitude decreasing from west to east across the boundary. These different dryline characteristics have important implications on the mesoscale lifting of moisture and subsequent advection to the east impacting the maintenance, motion, and structure of the dryline and its diurnal evolution (see Ziegler and Hane 1993).

Figure 5 shows that the vertical velocity extremes in the moist part of the leg were less intense in magnitude than in the drier side. The findings for this leg were representative of the entire set of UWKA flight legs on this day (not shown here). In addition, the larger-scale updrafts and downdrafts (shown by a heavy smoothed line, about 4-5 km wide) were composed of several small-scale perturbations (1 km or less). The larger scales were identified in the FMCW and SRL data, as discussed later. The vertical velocities varied between -3.0 and $3.0 \mathrm{~m} \mathrm{~s}^{-1}$, with an average value of $-0.5 \mathrm{~m} \mathrm{~s}^{-1}$ for the entire leg. Note that the UWKA vertical velocity measurements are believed to be accurate to at least $0.5 \mathrm{~m} \mathrm{~s}^{-1}$ for instantaneous measurements and to at least $0.25 \mathrm{~m} \mathrm{~s}^{-1}$, possibly to $0.1 \mathrm{~m} \mathrm{~s}^{-1}$, for long-track averages (Geerts and Miao 2005). These vertical velocity values are similar to those observed by the MAPR. Weiss et al. (2006) also found that the UWKA-derived maximum updraft speeds in the eastern dryline (D1), averaged over a distance of about $500 \mathrm{~m}$, were about 3 $\mathrm{m} \mathrm{s}^{-1}$. Moreover, they show that both ground-based and airborne Doppler radar data within the same dryline plume, averaged over the same width, also peak between 3 and $4 \mathrm{~m} \mathrm{~s}^{-1}$. However, at finer scales (reso- 


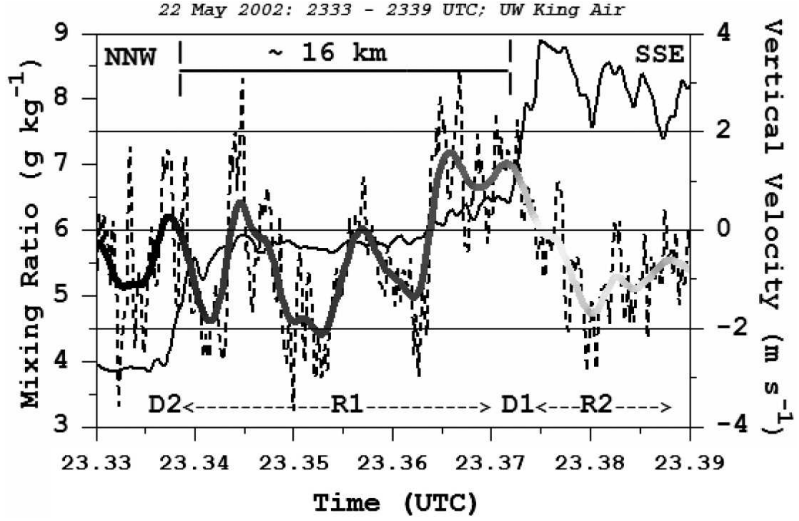

FIG. 5. Water vapor mixing ratio (solid curve) and vertical velocity (dotted curve) data collected by in situ probes aboard the UWKA. A heavily smoothed plot of the vertical velocity data is also shown (thick gray curve). Values shown are for a single leg at $1.6 \mathrm{~km}$ AGL as UWKA flew from NNW to SSE across the field of cumulus clouds (its relative location is shown in Fig. 3). Approximate locations of D1, D2, R1, and R2 (refer to Fig. 2) are shown.

lutions between 10 and $100 \mathrm{~m}$ ), the updraft vertical velocities were frequently observed to be comprised between 6 and $9 \mathrm{~m} \mathrm{~s}^{-1}$.

\section{2) Across-DRYLINE MOISTURE VARIABILITY ON BOARD THE NRL P-3}

During IHOP_2002 CI missions, the NRL P-3 aircraft was dedicated to the documentation of along- and across-dryline thermodynamic characteristics using both remote sensing and in situ measurements. Remote sensing instruments included the airborne water vapor differential absorption lidar (DIAL), Lidar pour l'Etude des Interactions Aérosols Nuages Dynamique Rayonnement et du Cycle de l'Eau-lidar (LEANDRE 2, or L2; Bruneau et al. 2001), and the airborne Electra Doppler radar/Analyse Stéréoscopique pour Radar à Impulsions Aéroporté (ELDORA/ASTRAIA). The NRL P-3 sampling strategy was as follows: the NRL P-3 flew long east-west survey legs in the region of Homestead (where the convection was forecasted to be initiated), in order to detect boundaries/drylines. Upon detecting the boundaries D1 and D2, the NRL P-3 flew elongated box patterns around boundary D1 (which was better defined than boundary D2 at the time of the survey), the longest dimension of the box being parallel to the dryline.

In this section, we examine the horizontal variability of the moisture field in the BL as observed by $\mathrm{L} 2$ on 22 May 2002 along one of the early east-west survey legs (shown in Fig. 1). Horizontal pointing DIAL measurements made in the framework of IHOP_2002 provided the first ever lidar observations of the horizontal structure of the water vapor field in the vicinity of drylines.

The two-dimensional horizontal structure of the water vapor field measured by L2 at $1.2 \mathrm{~km}$ above ground level (AGL) across the boundaries D1 and D2 between 2037 and 2056 is shown in Fig. 6a. A gap (approximately $25 \mathrm{~km}$ of a $125-\mathrm{km}$-long leg) is observed in the L2 data that results from an unfortunate L2 operator maneuver. The along-track resolution is $5 \mathrm{~s}$, which translates to a spatial resolution of $0.7 \mathrm{~km}$ (assuming an average aircraft speed of $140 \mathrm{~m} \mathrm{~s}^{-1}$ ). As discussed in Bruneau et al. (2001), L2 water vapor mixing ratio retrievals have a precision better than $0.5 \mathrm{~g} \mathrm{~kg}^{-1}$ within a $5-\mathrm{km}$ distance from the aircraft and an along-beam resolution of $300 \mathrm{~m}$. In the configuration for the 22 May operation, reliable retrievals of water vapor mixing ratio were obtained at distances ranging from 1.2 to 2.7 $\mathrm{km}$ from the aircraft; saturation of the lidar signal at close range and attenuation at far range limiting data quality (see details in Murphey et al. 2006). Homestead was located just east of the eastern dryline (D1) at the time of the P-3 survey leg.

Figure $6 \mathrm{~b}$ shows a comparison of the water vapor mixing ratio measured in situ by the NRL P-3, and the range-averaged $\mathrm{L} 2$ data between 1.35 and $2.25 \mathrm{~km}$ from the aircraft. Excellent agreement is found between the two curves. Three distinct regions are identified from the water vapor mixing ratio evolution on the eastwest NRL P-3 transect. East of D1 (located around $-100.8^{\circ} \mathrm{E}$, i.e., east of Homestead at 2047), water vapor mixing ratios were between 8 and $10 \mathrm{~g} \mathrm{~kg}^{-1}$. Between D1 and D2, the water vapor mixing ratios dropped to about $5-6 \mathrm{~g} \mathrm{~kg}^{-1}$. The water vapor mixing ratio gradient across D2 was about $1 \mathrm{~g} \mathrm{~kg}^{-1}$ — a much weaker drop than that across D1 $\left(3 \mathrm{~g} \mathrm{~kg}^{-1}\right)$. West of D2, water vapor mixing ratio values were generally less than 3 to $4 \mathrm{~g}$ $\mathrm{kg}^{-1}$. Note that the water vapor mixing ratio values in region R2 (east of D1) were similar to that measured by in situ UWKA instruments almost $3 \mathrm{~h}$ later (2333-2339) while to the west of $\mathrm{D} 1$, the air mass was slightly drier (by about $0.5 \mathrm{~g} \mathrm{~kg}^{-1}$ ) at the earlier time of the NRL P-3 passage. This may be partly due to the convective mixing process.

\section{Remote sensing data at Homestead}

Remote sensing data acquired at the IHOP_2002 Homestead profiling site on 22 May 2002 are shown in Figs. 7 and 8. The figures show time-height data of wind speed and direction, water vapor mixing ratio, potential temperature, BL height, BL standard deviation, and vertical velocity profiles as the dryline advanced and retreated over the site. A brief summary of 

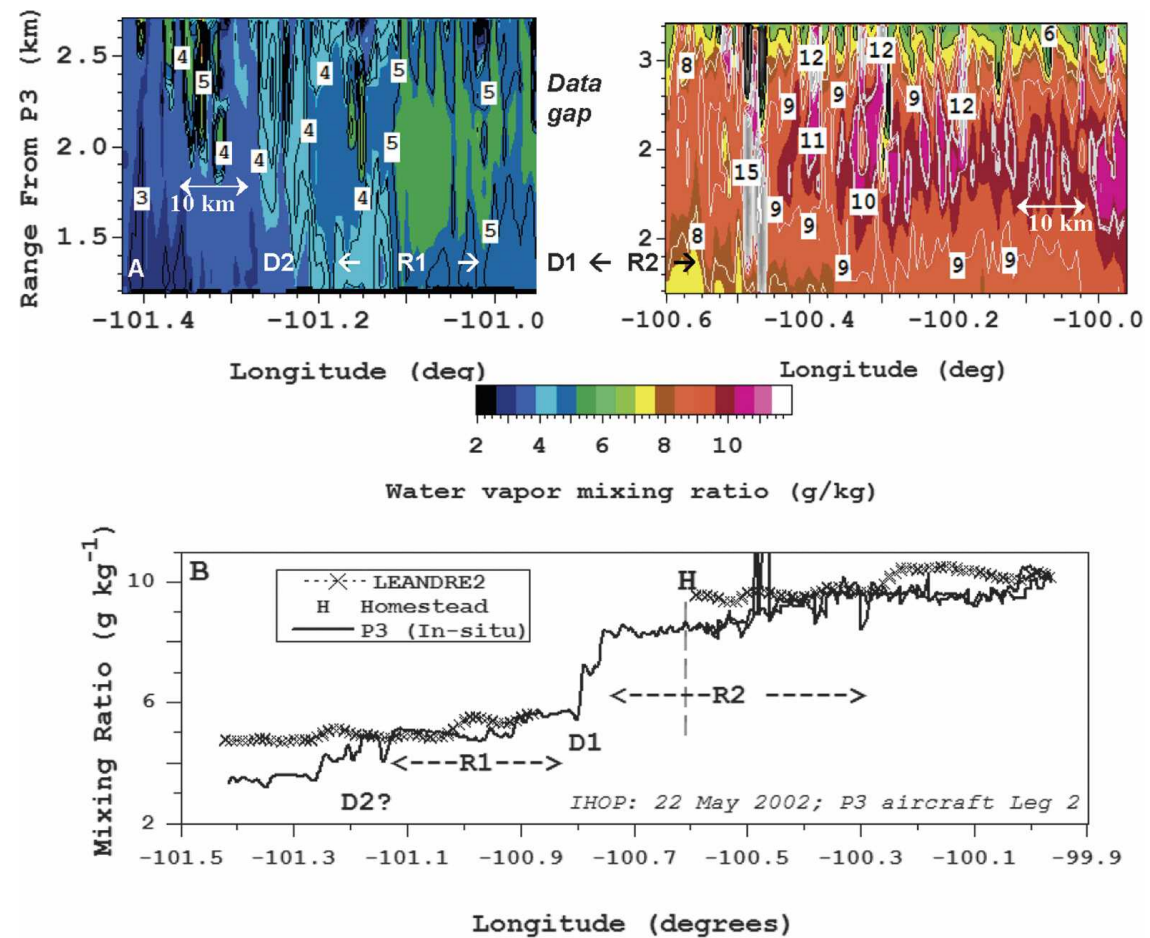

FIG. 6. (a) Water vapor mixing ratio $\left(\mathrm{g} \mathrm{kg}^{-1}\right)$ profile measured by the LEANDRE II on the NRL P-3 on an E-W flight leg about 3-4 km to the south of the IHOP_2002 profiling site (see Fig. 1). The lidar was pointed horizontally from P-3 (flying at 1-1.2 km AGL between 2037 to 2056 UTC) on this flight leg. (b) Time series comparison of the integrated L2 and in situ P-3 water vapor mixing ratio data. Approximate positions of the IHOP_2002 profiling site (H) and relevant boundaries (D1, D2, R1, R2) as well as distance scales are also shown.

the data and other details (averaging times, resolution, etc.) are given below. The FMCW data is presented in section 4.

(i) Horizontal wind. Figures 7a and 7b show GLOW measurements of horizontal wind speed and direction. The wind measurements plotted here are 10min average profiles and have $100-\mathrm{m}$ vertical resolution. The lidar wind measurement accuracy is range dependent. For the profiles shown, the error does not exceed $3 \mathrm{~m} \mathrm{~s}^{-1}$ and is considerably smaller at lower altitudes. The prevailing wind prior to 2200 was from the south-southwest $\left(180^{\circ}-\right.$ $220^{\circ}$ ) through most of the BL, while being more westerly at higher altitudes. The shift from southerly to southeasterly winds below $1 \mathrm{~km}$ AGL after about 2330 is consistent with surface observations discussed in sections $2 \mathrm{~b}$ and $2 \mathrm{c}$. Wind speeds below $0.5 \mathrm{~km} \mathrm{AGL}$ were on the order of $15 \mathrm{~m} \mathrm{~s}^{-1}$. Wind speed increased with altitude, reaching 25-30 $\mathrm{m} \mathrm{s}^{-1}$ by $2-3 \mathrm{~km}$ AGL. The data gap between 2200 and 2330 was a result of sector scan operation mode made at several elevation angles to ascertain variations in dryline-associated flows (not shown).
Hence, no GLOW data were available during the passage of the wedge-shaped region over Homestead. Nevertheless, GLOW data were important in understanding the mechanisms at play during the overpass of the convergence zone labeled R3 in the early hours of 23 May.

(ii) Water vapor mixing ratio. The water vapor mixing ratio measured by the SRL between $\sim 2000$ on May 22 and $\sim 0300$ on 23 May 2002 are shown in Fig. 7c. The SRL data were smoothed with a 3-min running window resulting in approximately 2 -min temporal resolution as determined by Fourier spectral analysis. In addition, variable vertical smoothing was used to minimize errors due to daytime background light. The random error in the SRL mixing ratio data is $10 \%$ or less in the boundary layer during the daytime but increases rapidly above the boundary layer due to drier conditions. Under nighttime conditions, the random error is less than $2 \%$ in the boundary layer and reaches $10 \%$ at $6 \mathrm{~km}$. The figure shows the development of the afternoon CBL and subsequent cloud formation (seen as white vertical stripes above $3 \mathrm{~km}$, a 

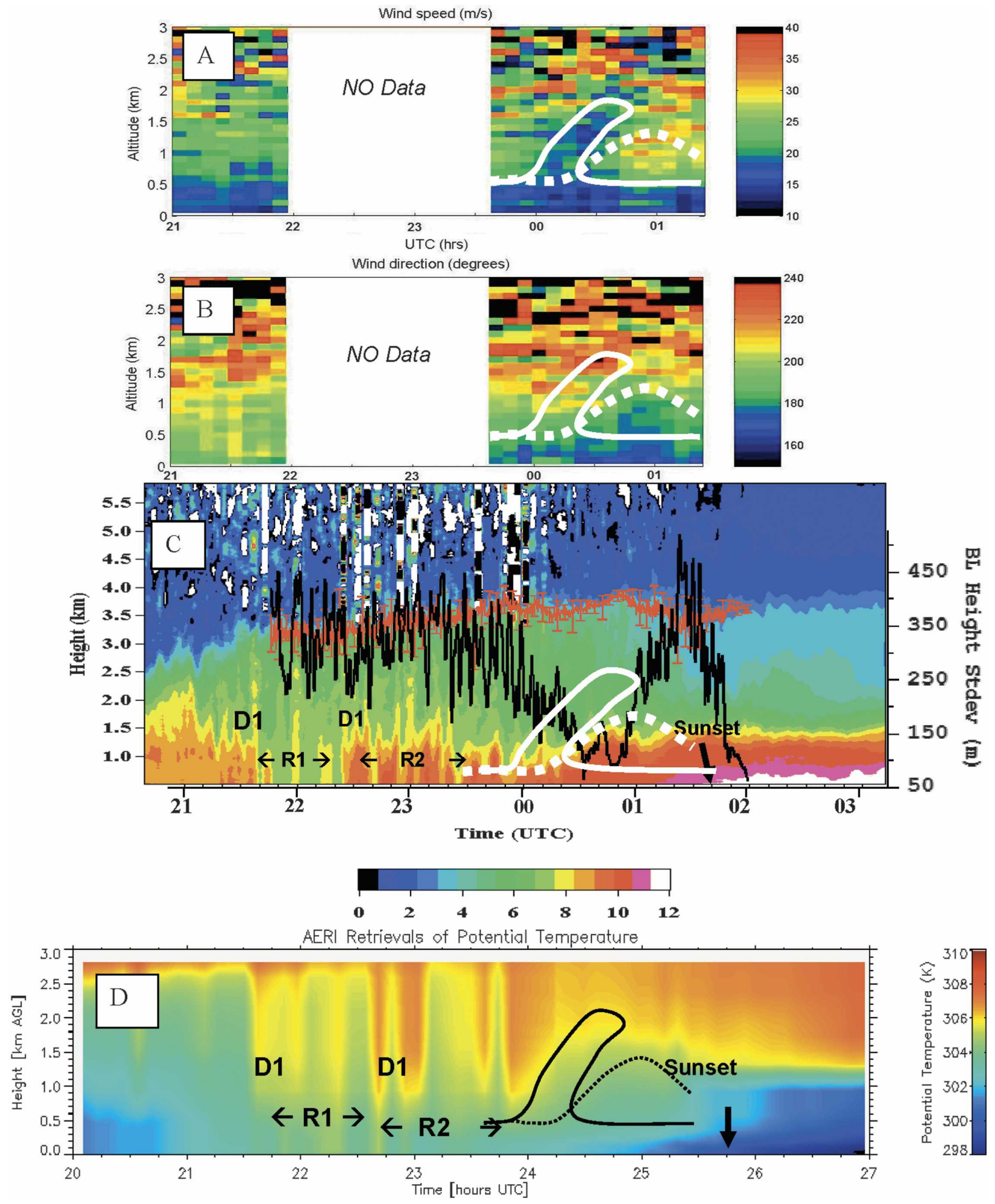

FIG. 7. Time-height plot of (a), (b) GLOW measurements of the wind speed and direction, (c) SRL-measured water vapor mixing ratio with overlay of HARLIE-derived BLH (red) and its standard deviation (black), and (d) AERI-retrieved profiles of potential temperature at the IHOP_2002 profiling site on 22 May 2002. The location of clouds is shown by the base of the white strips on the SRL image [(c)]. Approximate locations of eastern dryline (D1) and regions R1 and R2 are indicated. Approximate boundaries outlining the wind convergence zone are also shown. Note that 25, 26, and 27 in the time scale in (d) correspond to 0100, 0200, and 0300 UTC, respectively. Note also that the vertical scale for (c) is different from the others. 


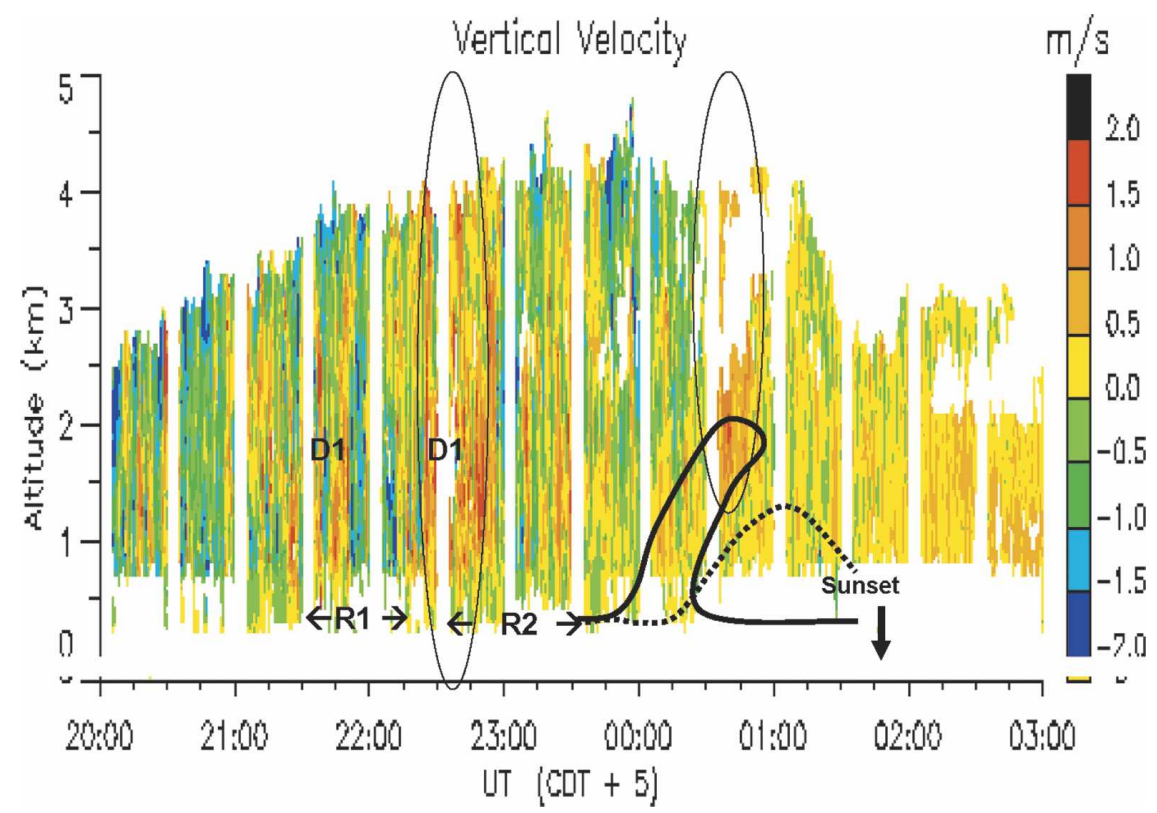

FIG. 8. Time-height plot of the vertical velocity $\left(\mathrm{m} \mathrm{s}^{-1}\right)$ observed by the NCAR MAPR/ISS at the IHOP_2002 profiling site on 22 May 2002. Also shown are the relative locations, in time, of D1, R1, R2, the wind convergence boundaries from GLOW, sunset time, and oval regions of relatively high vertical velocity.

result of complete attenuation of the laser beam), the brief intrusion of a drier air mass between 2140 and 2230 (associated with R1), the moistening that followed (associated with R2), and the sudden drying in the upper parts of the BL starting prior to sunset.

(iii) Boundary layer height. The HARLIE-derived BL height (BLH; red curve) and the standard deviation of the BLH (black curve) for the same time are also plotted over the SRL water vapor image (Fig. 7c). HARLIE (rotating in azimuth, $45^{\circ}$ from zenith) offers the advantage of looking at the "spatial" variability of the BL structural parameters over a circular radius of several kilometers. For each scan (about 36 backscatter profiles per scan), the average BLH and the BLH standard deviation can be computed. The BLH is determined from the HARLIE aerosol backscatter measurements using a wavelet-based analysis method (see Davis et al. 2000). Note that after sunset, the HARLIEderived BLH remained above $3.0 \mathrm{~km}$ MSL, thereby capturing the top of the residual layer and not the developing nocturnal BL, as is generally the case with backscatter lidars. A better approximation of the nocturnal BL (estimated from sounding and other datasets) follows the $5 \mathrm{~g} \mathrm{~kg}^{-1}$ (green contour line) water vapor contour (Fig. 7c).

(iv) Temperature. Time-height cross sections of AERI- derived potential temperature data for 22 May 2002 are plotted in Fig. 7d. Although, the data were recorded at 10-min resolution, the large-scale variations in the temperature evolution correlate well with the 2-min SRL observations of water vapor mixing ratio (Fig. 7c). Most notable are 1) the increase in temperature by about $2^{\circ}$ throughout the entire BL in region R1 ( 2140-2230), which was associated with a drop in water vapor mixing ratio from $8-9 \mathrm{~g} \mathrm{~kg}^{-1}$ to about $6 \mathrm{~g} \mathrm{~kg}^{-1}$, and 2) the cooler regions in the pre-2100 and post-2300 periods. These measurements confirm the earlier findings that the wedge-shaped air mass (R1) was drier and warmer over the Homestead site.

(v) Vertical velocity. MAPR-measured vertical velocities on 22 May 2002 are shown in Fig. 8. The vertical resolution was typically $100 \mathrm{~m}$, although there were periods when the radar was operated in a $20-\mathrm{m}$ vertical resolution mode ( $\mathrm{Yu}$ and Brown 2004). The time resolution of the vertical velocity measurements reported here is $30 \mathrm{~s}$. The antenna beamwidth (full width half power) is about $8^{\circ}$, which corresponds to a sampling volume of $140 \mathrm{~m}$ across at $1-\mathrm{km}$ range. Although the 5-min data gaps, used to operate the Radio Acoustic Sounding System (RASS), and the many data dropouts complicate accurate visualization of the coherence in the updraft speed with altitude, the MAPR data 
were adequate to ascertain that updraft cores were observed throughout the BL (Fig. 8). Updraft speeds of up to about $3.0 \mathrm{~m} \mathrm{~s}^{-1}$ were observed at the $1.5-\mathrm{km}$ level around 2230 , near the main dryline (D1), but the bulk of the vertical velocities were between -1.0 and $1.0 \mathrm{~m} \mathrm{~s}^{-1}$, in agreement with in situ aircraft measurements. Note that these values may be biased down by $0.1-0.3 \mathrm{~m} \mathrm{~s}^{-1}$ overall due to influence attributed to insects and the relatively large sensing volume by the instrument (Angevine 1997). Moreover, note also that instantaneous updraft vertical velocities of up to 8-9 $\mathrm{m} \mathrm{s}^{-1}$ are reported for this case by Weiss et al. (2006) for smaller time- and space-sensed volumes using a different approximation technique, as discussed in section $2 \mathrm{e}(1)$ above.

\section{Discussion}

\section{a. Moisture variability in the convective boundary layer}

In Fig. 9a, an overlay of the SRL-measured water vapor mixing ratio field (shown in Fig. 7c) on the FMCW-derived structure function profile is shown. The FMCW radar echo is expressed in terms of the logarithm of the structure function (Ince et al. 2003), $C_{n}^{2}$, plotted at 2-s resolution. The SRL data (2-min temporal resolution) are interpolated to FMCW temporal resolution. The FMCW radar echo is expressed in terms of the logarithm of the structure function (Ince et al. 2003), $C_{n}^{2}$, plotted at 2-s resolution. Most interesting in the FMCW data is the coherent backscatter from surface to the top of the CBL before 0030 illustrating plumes of enhanced structure-function values. These higher signal values are a result of an enhanced scattering by convective plumes of air as they rise to the top of the BL and are assumed to be primarily due to changes in temperature and moisture. The strong echo variations and the general trend of the echo tops reveal the convective plumes (before 0030) and the growth and demise of the afternoon BL, respectively. A detailed look at the structure function plot of these plumes reveals a variable width organization, wider at the base and narrowing with altitude with most of them reaching the $2-2.5-\mathrm{km}$ level (see inset in Fig. 9a). The width of the base (in minutes) and the distance between each of these plume structures was variable and better defined above $1.5 \mathrm{~km}$. The duration in time of the plumes varied between about 2 and 9 min. Using a wind speed of about $15 \mathrm{~m} \mathrm{~s}^{-1}$, these translate to an inferred plume width of about $2-8 \mathrm{~km}$, a wider range than that derived from multiple-Doppler radar data (Buban et al. 2003).
After 0030, with the arrival of the wind convergence zone (labeled R3 in Fig. 2), the convective plume structure ceased and an elevated enhanced reflectivity region emerged that correlated well in time with the elevated vertical velocity observed at this time (Fig. 8), the moisture "bulge" (increase in depth) in the SRL data, and GLOW-based wind speed decrease and direction change boundary lines (overlaid).

A number of additional points can also be made by comparing the SRL and FMCW overlay: (i) Cumulus clouds were observed by SRL starting about 2130 and cloud-base height was on average about $3.4 \mathrm{~km}$. For nearly all the lidar observations of cloud base, there were underlying enhanced echo plumes in the FMCW reaching as high as $2.5 \mathrm{~km}$ (see inset Fig. 9a). A similar moisture enhancement was observed in the SRL water vapor mixing ratio profile data coincident with the FMCW plumes. (ii) A majority of the plumes from the FMCW corresponded, in time, to the plumes of moisture in the water vapor mixing ratio profiles from the SRL. This is particularly true for altitudes higher than about $1 \mathrm{~km}$. This is remarkable given that these two different datasets were sampled at two different resolutions.

A direct outcome of Fig. 9a is the determination of the "in plume" versus "out-of-plume" moisture content. To accomplish this, the time of occurrence of the plumes using FMCW data was first determined and then the water vapor mixing ratio profile at that time was selected from the SRL data. Note, however, that this characterization is limited to the SRL temporal resolution. Fortunately, the FMCW shows that a lot of these cores are more than a couple of minutes in duration (with a majority of them 5-6 min wide) and thus characterization of their moisture can be done adequately using the SRL profiles. For example, the average water vapor mixing ratio calculated using the described method at a given altitude $(2 \mathrm{~km})$ for the updraft and downdraft cores was found to be $6.5 \pm 0.5$ and $5.7 \pm 0.1 \mathrm{~g} \mathrm{~kg}^{-1}$, respectively. This is similar to the variations observed between boundary layer roll updraft and downdraft regions (Weckwerth et al. 1996). This difference was also observed below the 1-km level. To demonstrate that these plume structures extend the entire BL depth, we plot water vapor moisture directly under a cloud and mixing ratio profile in the cloud-free environment (Fig. 9c). It shows the entire subcloud layer to be moister by up to $1.5 \mathrm{~g} \mathrm{~kg}^{-1}$.

Another point to note in Fig. $9 \mathrm{~b}$ is the temporal trend of water vapor mixing ratio at two levels in the CBL (1.0 and $2.5 \mathrm{~km} \mathrm{AGL).} \mathrm{The} \mathrm{mixing} \mathrm{ratio} \mathrm{values} \mathrm{at} 2.5$ $\mathrm{km}$ increased with time until about 2145, remaining constant for about $1 \mathrm{~h}$ (2140-2230) before slightly de- 

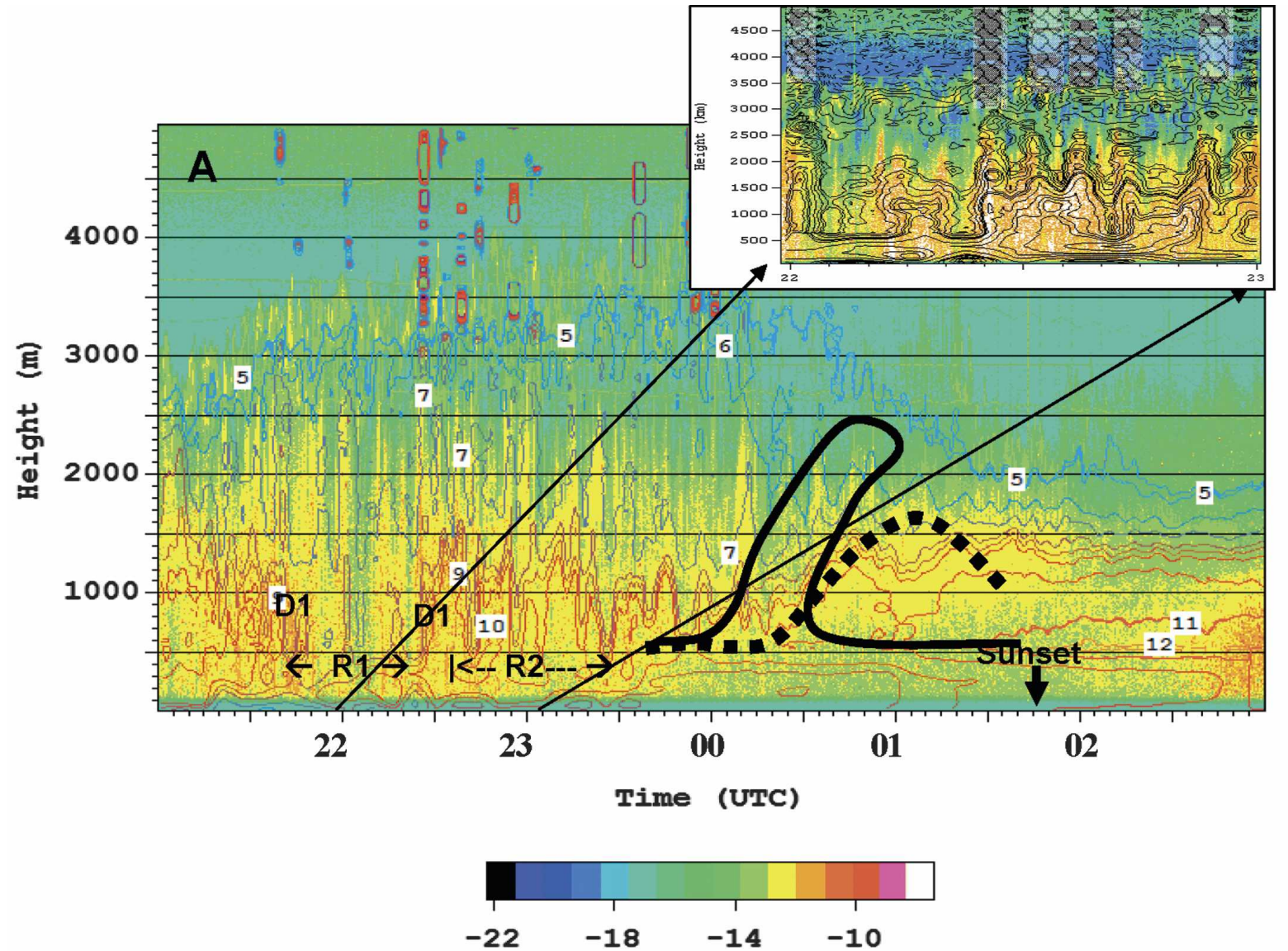

Relative Radar Backscatter (CN2)
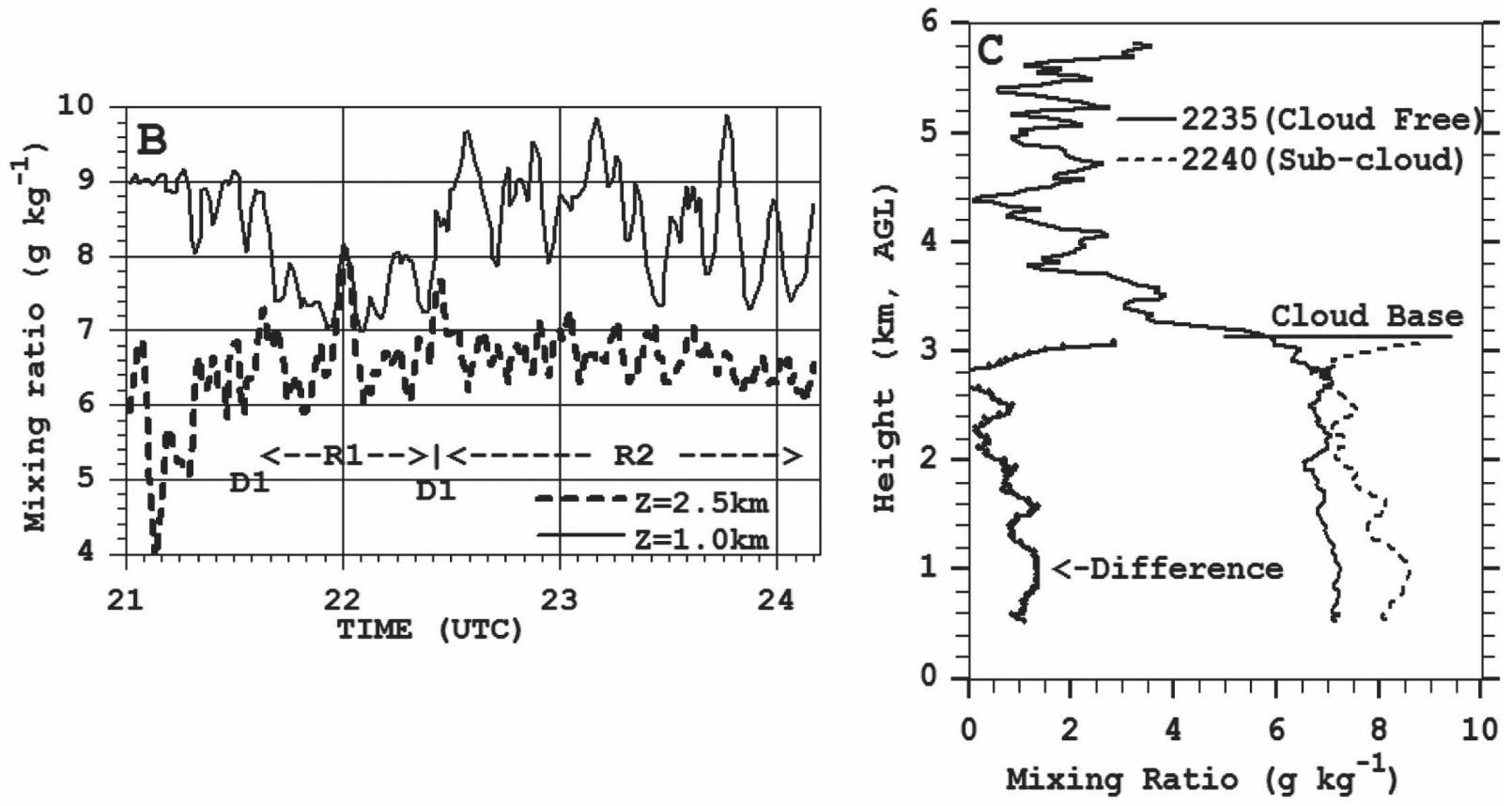

FIG. 9. (a) An overlay of SRL water vapor mixing ratio (contour) and refractivity profiles from the FMCW (background). The inset is a zoom-in plot for 2200-2300 UTC, showing cloud locations (SRL derived) on top of updraft cores (vertical plumes). (b) Example of time series water vapor mixing ratio data at 1 (solid line) and $2.5 \mathrm{~km}$ (dashed line), and (c) examples of profiles of mixing ratio from within (subcloud region) and outside an updraft core in (a), showing cloud-base-height location and the difference in mixing ratio. 
creasing. At $1 \mathrm{~km}$ AGL, the pre-2140 trend was reversed and was followed by a period of relatively constant values (2140-2230). The post-2230 trend at $1 \mathrm{~km}$ AGL was marked by several oscillations and an increase of mixing ratio to an average of close to $9 \mathrm{~g} \mathrm{~kg}^{-1}$. Several processes are at play here. In the pre-2140 time period convection dominated, thereby mixing moisture upward and thus leading to an increase (decrease) of moisture at higher (lower) altitudes. In region R1, the upward moisture transport due to convection led to a constant mixing ratio value of $5-6 \mathrm{~g} \mathrm{~kg}^{-1}$ throughout the CBL. This, combined with observations of cumulus but not deep convection in this region, suggests adequate updraft was available for air parcels to reach the lifting condensation level (LCL) but not the level of free convection (LFC). Estimated levels for LCL (LFC) at Homestead around 2130-2330 varied considerably but were about $3.4 \mathrm{~km}(\sim 3.6 \mathrm{~km})$. Later, east of D1 and after sunset, the trend (gradual decrease) at higher elevations can be attributed to absence of convection, and thus the lack of surface moisture transport from below. However, at $1 \mathrm{~km}$ (and lower), advection associated with the north-flowing cool, moist air mass dominated and led to increased moisture.

\section{b. Wind convergence zone east of the main dryline}

An interesting evolution of the wind direction and speed with altitude was observed between 2330 and 0100 (Figs. 7a,b), 20-25 km to the east of the retreating dryline (D1). The depth of the southerly $\left(\sim 170^{\circ}-190^{\circ}\right)$ air gradually increased to about $1 \mathrm{~km}$ while at the same time wind speed values decreased in an eastward-tilted vertical region of about $1.5 \mathrm{~km}$ in depth followed by an increased horizontal wind speed region. This zone of convergence was associated with the broad area of enhanced radar reflectivity at 0000 (outside the S-Pol refractivity range) in Fig. 2 (labeled R3), and a cool air mass of potential temperature of less than about $305 \mathrm{~K}$ (Fig. 7d) as observed with AERI.

A plot of horizontal wind speed and water vapor mixing ratio in this convergence region is shown in Fig. 10. A prominent feature of this wind convergence zone is the moisture bulge to its immediate east followed by a dip as evidenced by the $9 \mathrm{~g} \mathrm{~kg}^{-1}$ contour line (thick white dashed line). Moisture was lifted by about $0.7 \mathrm{~km}$ to form the bulge followed by a drop at about 0100 . MAPR-derived data for this region show high values of vertical velocity $\left(>1.5 \mathrm{~m} \mathrm{~s}^{-1}\right)$ between 1 and $2 \mathrm{~km} \mathrm{AGL}$ coinciding with the onset of the horizontal wind decrease and moisture bulge ( $\sim 0045)$. The subsidence region was associated with higher horizontal wind speeds and slightly negative $\left(-0.5 \mathrm{~m} \mathrm{~s}^{-1}\right)$ values of vertical velocity. This region was also associated with high vari-

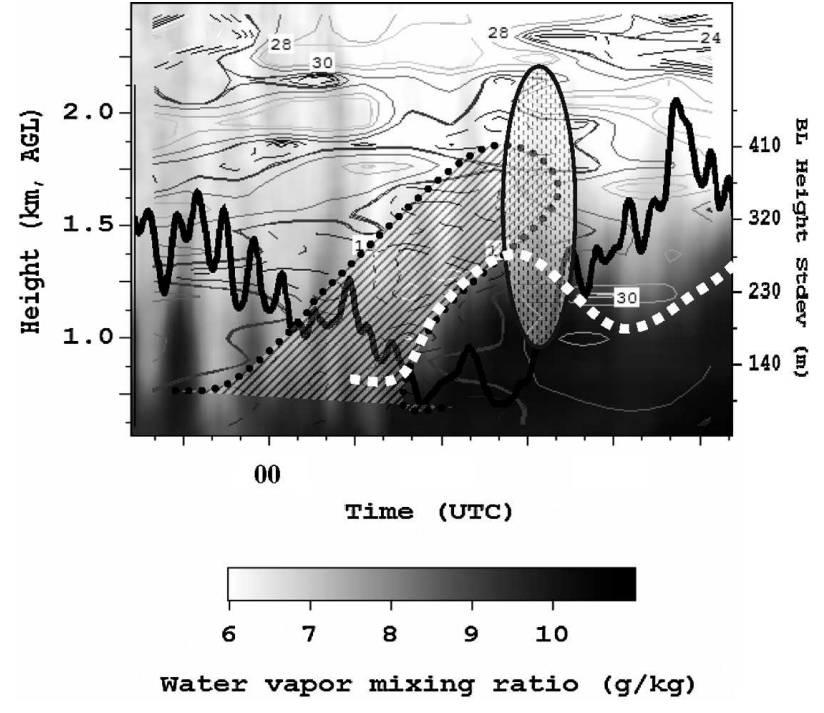

FIG. 10. SRL water vapor mixing ratio (gray shading background) and GLOW-measured winds speed in $\mathrm{m} \mathrm{s}^{-1}$ (contour lines) on 22 May 2002 at the IHOP_2002 profiling site. Regions of relatively low $\left(<20 \mathrm{~m} \mathrm{~s}^{-1}\right)$ horizontal wind speed (dashed curves; note the tilted region outlined by dots), high vertical velocity (as high as $3 \mathrm{~m} \mathrm{~s}^{-1}$; elliptical region), HARLIE-derived standard deviation of the BL top (thick black line), as well as an approximate outline of the $9 \mathrm{~g} \mathrm{~kg}^{-1}$ mixing ratio contour (white dotted line), are identified.

ability in the lidar-derived BL height (seen in the BLH standard deviation), which may be caused by the overturning of air parcels, as can be caused by waves and/or turbulence. This observation of the horizontal wind decrease accompanied by an increase in vertical velocity and moisture uplift, followed by a core area of increased horizontal wind speed, is analogous with the structure of the "nose" of a density current, similar to what was reported by Atkins et al. (1998). Unlike Atkins et al. (1998), however, this convergence occurred well to the east of the main dryline (D1). Note also that although the BLH, its variability, vertical velocity, and water vapor mixing ratio were at or near peak values for the day during this period, no cloud development was observed.

\section{c. Implication for convection initiation}

Vigorous mixing during the daytime and large-scale ascent slightly west of the eastern dryline convergence zone were noted. Also noted were relatively larger CAPE and low CIN in the wedge-shaped region west of and adjacent to the main dryline, a necessary but not sufficient condition for convection initiation. This suggests that while the LCL was reached by the rising parcels of moist air (evidenced by the cumulus clouds) the LFC was not. Weiss et al. (2006) have identified a con- 
siderable tilt to the east in the dryline convergence zone above $1.5 \mathrm{~km}$ AGL, suggesting that the relatively drier air from the region bounded by the two drylines was overrunning the moist air to the east, similar to a density current. Hence, we believe that likely reasons for the lack of CI along the eastern dryline are strong capping inversion and moisture detrainment between the lifting condensation level and the level of free convection related to the overriding drier air (Ziegler and Rasmussen 1998). In addition, the relatively small and homogenous BL moisture values (less than $10 \mathrm{~g} \mathrm{~kg}^{-1}$ ) in region R1, although an indication of efficient mixing of moisture, points to the lack of sufficient moisture supply for CI. Near sunset, the area $20-25 \mathrm{~km}$ east of the main dryline (D1) was also associated with a wind convergence zone leading to a bulge in the BLH. This lift was not associated with cloud development and occurred much later and east of the cumulus cloud observation region. In summary, neither the daytime convection near the main dryline nor the wind convergence east of the dryline lead to appreciable convection initiation in the area.

\section{Summary and findings}

Measurements made by an array of instruments during a dryline passage that occurred in western Oklahoma on 22 May 2002 during the International $\mathrm{H}_{2} \mathrm{O}$ Project are presented. The paper primarily presents analyses of the datasets collected by the ground-based lidar and radar profilers at the profiler site in the Oklahoma panhandle that we refer to here as Homestead. The analysis is complemented by data collected from conventional surface and upper-air observations as well as aircraft-based lidar and radar instrumentation. Findings are summarized below:

1) A wedge-shaped region of a well-mixed and cumulus-cloud-topped convective boundary layer bounded by sharp moisture gradients to its east and west edges separated a very warm, dry region to the west from a moist, cool region to the east. The east and west moisture convergence zones formed the double-dryline feature on the day leading to three different moisture and temperature regions with different boundary layer characteristics that advanced and retrograded over the sampling site. The wedgeshaped region was characterized by a well-mixed moisture profile throughout the BL (although the mixing ratio values were not as high; generally less than $10 \mathrm{~g} \mathrm{~kg}^{-1}$ ) and relatively higher CAPE (and low CIN) compared to the immediate west and eastern regions. Adequate lift was available to get par- cels to the LCL but not the LFC. A strong westerly wind and an eastward-tilted boundary were observed near the dryline, leading us to speculate that strong capping inversion and moisture detrainment between the lifting condensation level and the level of free convection related to the overriding drier air were detrimental to $\mathrm{CI}$ in this case.

2) The lidar-observed afternoon boundary layer revealed a highly variable moisture organization at Homestead, starting with an average of about 8-9 g $\mathrm{kg}^{-1}$ water vapor mixing ratio in the lowest $1 \mathrm{~km}$ prior to 2130 and dropping abruptly to $6-7 \mathrm{~g} \mathrm{~kg}^{-1}$ and a well-mixed convective boundary layer between 2130 and 2230 and changing back once again to a more moist environment at low levels (up to 12 $\mathrm{g} \mathrm{kg}^{-1}$, later near sunset). These changes were related to the advancing and retrograding dryline on this day, and the moisture contrasts were mainly between the wedge-shaped air mass and the air east of the main (eastern) dryline convergence zone. The driest (westernmost) region did not move east far enough over Homestead to be sampled by the profiling instruments, but aircraft measurements revealed water vapor mixing ratio values of less than 4 $\mathrm{g} \mathrm{kg}^{-1}$ at $1.6 \mathrm{~km}$-equivalent to values recorded at altitude of $3.5 \mathrm{~km}$ AGL and above at Homestead.

3) Simultaneous analysis of the radar, profiler, surface time series, and lidar data revealed this wedge zone was populated by updraft plumes spanning up to 5-6 min (a width of up to $7 \mathrm{~km}$ as inferred for a 14-16 $\mathrm{m} \mathrm{s}^{-1}$ wind speed) rising to cloud base, similar to the scales observed in the aircraft data. The in-plume moisture was greater by an average of about $1 \mathrm{~g}$ $\mathrm{kg}^{-1}$ or more over the surrounding air at $2-\mathrm{km}$ height and through most of the lower boundary layer. Updraft speeds of $3 \mathrm{~m} \mathrm{~s}^{-1}$ and higher were associated with rising plumes near the main dryline convergence zone by both the ground-based profiler and the UWKA in situ probes, much lower than the instantaneous values of $8-9 \mathrm{~m} \mathrm{~s}^{-1}$ reported by Weiss et al. (2006) using pseudo-multiple-Doppler radar techniques in the same general area for the same dryline case, but for much shorter spatial scales.

4) The CBL spatial and temporal variability was well documented using a new scanning lidar technique that quantified the small-scale horizontal variability of BLH. The peak-to-peak variation of the standard deviation of the BLH within about a radius of 6-7 $\mathrm{km}$ around Homestead between 2130 and 0100 varied from a low of about $250 \mathrm{~m}$ to about $400 \mathrm{~m}$ while the BLH steadily increased to $3.6 \mathrm{~km}$. The BLH standard deviation was a much better indicator of the variability (activity) of the CBL as well as other 
processes within the BL. For example, the standard deviation was at a minimum about an hour before sunset, indicating the cessation of convective processes and cloud dissipation.

Finally, most of the detailed measurements of drylines and our knowledge of conceptual models depend on measurements made during different portions of dryline lifetimes (see Parsons et al. 2000 for a discussion). We believe that observational data and studies of the dryline over several diurnal cycles are important for validation of conceptual models and highresolution numerical simulations. This study provides insight into the moisture, wind, and temperature evolution of a dryline case during late afternoon and early evening. The presentation here uses only a small subset of the many available data from many instruments for this case study. Several mobile radars and an armada of mobile-mesonet instrumentation were also deployed on this day, a subject of a paper in this volume (Weiss et al. 2006) and many others planned. A clearer picture of the dryline on 22 May 2002 will only emerge after coalition of the many different datasets and models, which include investigating the effect of differential heating coming from differences in vegetation cover, available water at the surface for evaporation, and convective roll development in the dry air. Analysis of all these observations and numerical model runs may lead to definitive answers on why convection did not develop on this day and will enhance our knowledge of dryline evolution. This study adds to that effort by documenting and discussing the remote sensing observations made by a unique set of collocated lidar and radar instruments.

Acknowledgments. This research was supported by National Science Foundation Grant ATM-0129605 and the National Aeronauts and Space Administration (NASA). The authors are indebted to the many colleagues and researchers that made IHOP_2002 and associated observations possible. The paper has greatly improved from the input of the two anonymous reviewers.

\section{REFERENCES}

Angevine, W. M., 1997: Errors in mean vertical velocities measured by boundary layer wind profilers. J. Atmos. Oceanic Technol., 14, 565-569.

Atkins, N. T., R. M. Wakimoto, and C. L. Ziegler, 1998: Observations of the finescale structure of a dryline during VORTEX 95. Mon. Wea. Rev., 126, 525-550.

Bluestein, H. B., and S. S. Parker, 1993: Modes of isolated, severe convective storm formation along the dryline. Mon. Wea. Rev., 121, 1354-1372.
Bruneau, D., P. Quaglia, C. Flamant, M. Meissonnier, and J. Pelon, 2001: Airborne lidar LEANDRE II for water-vapor profiling in the troposphere. Appl. Opt., 40, 3450-3475.

Buban, M. S., C. L. Ziegler, and E. N. Rasmussen, 2003: The kinematic and thermodynamic effects of vortices within a dryline. Preprints, 31st Int. Conf. on Radar Meteorology, Seattle, WA, Amer. Meteor. Soc., CD-ROM, 11A.5.

Crook, A., 1996: Sensitivity of moist convection forced by boundary layer processes to low-level thermodynamic fields. Mon. Wea. Rev., 124, 1767-1785.

Davis, K. J., N. Gamage, C. R. Hagelberg, C. Kiemle, D. H. Lenschow, and P. P. Sullivan, 2000: An objective method for deriving atmospheric structure from airborne lidar observations. J. Atmos. Oceanic Technol., 17, 1455-1468.

Doswell, C. A., and E. N. Rasmussen, 1994: The effect of neglecting the virtual temperature correction on CAPE calculations. Wea. Forecasting, 9, 625-629.

Fabry, F., 2004: Meteorological value of ground target measurements by radar. J. Atmos. Oceanic Technol., 21, 560-573.

Feltz, W. F., H. B. Howell, R. O. Knuteson, H. M. Woolf, and H. E. Revercomb, 2003: Near continuous profiling of temperature, moisture, and atmospheric stability using the Atmospheric Emitted Radiance Interferometer (AERI). $J$. Appl. Meteor., 42, 584-597.

Geerts, B., and Q. Miao, 2005: The use of millimeter Doppler radar echoes to estimate vertical air velocities in the fairweather convective boundary layer. J. Atmos. Oceanic Technol., 22, 225-246.

Gentry, B., H. Chen, and S. X. Li, 2000: Wind measurements with a $355 \mathrm{~nm}$ molecular Doppler lidar. Opt. Lett., 25, 1231-1233.

Hane, C. E., C. L. Ziegler, and H. B. Bluestein, 1993: Investigation of the dryline and convective storms initiated along the dryline: Field experiments during COPS-91. Bull. Amer. Meteor. Soc., 74, 2133-2145.

- H. B. Bluestein, T. M. Crawford, M. E. Baldwin, and R. M. Rabin, 1997: Severe thunderstorm development in relation to along-dryline variability: A case study. Mon. Wea. Rev., 125, 231-251.

Ince, T., S. J. Frasier, A. Muschinski, and A. L. Pazmany, 2003: An S-band FMCW boundary layer profiler: Description and initial results. Radio Sci., 38, 1072, doi:10.1029/2002RS002753.

Kingsmill, D. E., 1995: Convection initiation associated with a seabreeze front, a gust front and their collision. Mon. Wea. Rev., 123, 2913-2933.

Koch, S. E., and J. McCarthy, 1982: The evolution of an Oklahoma dryline. Part II: Boundary-layer forcing of mesoconvective systems. J. Atmos. Sci., 39, 237-257.

Murphey, H. V., R. M. Wakimoto, C. Flamant, and D. E. Kingsmill, 2006: Dryline on 19 June 2002 during IHOP. Part I: Airborne Doppler and LEANDRE II analyses of the thin line structure and convection initiation. Mon. Wea. Rev., 134, 406-430.

Parsons, D. B., and Coauthors, 1994: The Integrated Sounding System: Description and preliminary observations from TOGA COARE. Bull. Amer. Meteor. Soc., 75, 553-567.

—, M. A. Shapiro, and E. R. Miller, 2000: The mesoscale structure of a nocturnal dryline and of a frontal-dryline merger. Mon. Wea. Rev., 128, 3824-3838.

Rhea, J. O., 1966: A study of thunderstorm formation along the dryline. J. Appl. Meteor., 5, 58-63.

Schaefer, J. T., 1974: The life cycle of the dryline. J. Appl. Meteor., 13, 444-449. 
—_, 1986: The dryline. Mesoscale Meteorology and Forecasting, P. S. Ray, Ed., Amer. Meteor. Soc., 549-572.

Schwemmer, G. K., 1998: Holographic airborne rotating lidar instrument experiment. Proc. 19th Int. Laser Radar Conf., Annapolis, MD, NASA, NASA/CP-1998-207671/PT2, 623-626.

Weckwerth, T. M., 2000: The effect of small-scale moisture variability on thunderstorm initiation. Mon. Wea. Rev., 128, 4017-4030.

_ - J. W. Wilson, and R. M. Wakimoto, 1996: Thermodynamic variability within the convective boundary layer due to horizontal convective rolls. Mon. Wea. Rev., 124, 769-784.

- and Coauthors, 2004: An overview of the International $\mathrm{H}_{2} \mathrm{O}$ Project (IHOP_2002) and some preliminary highlights. Bull. Amer. Meteor. Soc., 85, 253-277.

—, C. R. Pettet, F. Fabry, S. Park, and J. W. Wilson, 2005: Radar refractivity retrieval: Validation and application to shortterm forecasting. J. Appl. Meteor., 44, 285-300.

Weiss, C. C., H. B. Bluestein, and A. Pazmany, 2006: Finescale radar observations of the 22 May 2002 dryline during the
International $\mathrm{H}_{2} \mathrm{O}$ Project (IHOP). Mon. Wea. Rev., 134, 273-293.

Whiteman, D. N., 2003a: Examination of the traditional Raman lidar technique. I. Evaluating the temperature-dependent lidar equations. Appl. Opt., 42, 2571-2592.

- 2003b: Examination of the traditional Raman lidar technique. II. Evaluating the ratios for water vapor and aerosols. Appl. Opt., 42, 2593-2608.

Yu, T.-Y., and W. O. J. Brown, 2004: High-resolution atmospheric profiling using combined spaced antenna and range imaging techniques. Radio Sci., 39, RS1011, doi:10.1029/2003RS002907.

Ziegler, C. L., and C. E. Hane, 1993: An observational study of the dryline. Mon. Wea. Rev., 121, 1134-1151.

_ - and E. N. Rasmussen, 1998: The initiation of moist convection at the dryline: Forecasting issues from a case study perspective. Wea. Forecasting, 13, 1106-1131.

_ - T. J. Lee, and R. A. Pielke, 1997: Convective initiation at the dryline: A modeling study. Mon. Wea. Rev., 125, 10011026. 